\title{
Spanish Romancero in Russian and the semantization of verse form
}

\section{Vera Polilova*}

\begin{abstract}
In this paper, I analyze Russian translations and close imitations of Spanish Romancero poetry composed between 1789 and the 1930s, as well as Russian original poems of the same period marked by "Spanish" motifs. I discuss the Spanish romance as an international European genre, and show how this verse form's distinctive features were transferred into Russian poetry and how the Russian version - or, rather, several Russian versions - of this form came into being. I pay special attention to the genesis of the stanza composed of a regular sequence of feminine (F) and masculine (m) clausulae FFFm. In Johann Gottfried Herder's Der Cid, this clausula pattern was combined with unrhymed trochaic tetrameters, but, in early twentieth-century Russia, it emancipated from this metrical form, having retained the semantic leitmotifs of the Spanish romance, as well as its "Spanish" theme. I contextualize other translation equivalents of romance verse and compare them to the original Spanish verse form. I show (1) which forms poets used in translating romance verse and how those forms correlate (formally and functionally) with the original meter. Further, I discuss (2) when and how the trochaic tetrameters rhyming on even lines (XRXR) - originally used in translations of Spanish romances in German and English poetry - became the equivalent of romance verse in the Russian tradition. Finally, I demonstrate (3) how, in Konstantin Balmont's translations of Spanish poetry, the FFFm clausula pattern lost its connection with trochee. After Balmont, other poets of the Silver Age of Russian literature started using it in original non-trochaic compositions to express "Spanish" semantics.
\end{abstract}

Keywords: Romancero; poetic translation; "Spanish trochee"; unrhymed trochaic tetrameter; FFFm clausula pattern; semantics of meter

* Author's address: Vera Polilova, Institute of World Culture, Lomonosov Moscow State University, 1-51 Leninskie Gory, room 854, Moscow 119991, Russia. E-mail: vera.polilova@gmail.com. 


\section{Introduction}

\subsection{Generalities}

In her paper "Comparative Metrics and Comparative Literature", Rowena Fowler noted: "Metrical forms have never traveled as well as plots, themes, or genres, and they are often the first thing jettisoned by the translator" (Fowler 1977: 289). Although it is impossible to measure the degree of ease with which plots, themes and genres are transferred between languages and cultures compared to metrical forms, we should nevertheless note that the latter often travel more successfully and with more impressive results. To demonstrate this, it would suffice to mention, for instance, the fact that nearly all verse forms and verse systems in Russian versification were borrowed from non-Slavic European poetry.

The present article is the outcome of my research on the poetics of Russian translations of Spanish romances and original Russian poems with "Spanish" motifs written between 1789 and the 1930s. It is specifically devoted to a particular aim, namely: to demonstrate how, on Russian soil, the unrhymed clausula pattern FFFm, even without an obligatory connection to any particular meter (i. e., not only in combination with trochaic tetrameter) came to be associated with Spanish Romancero and Spain. I will also show that, in the Russian tradition, half-rhymed trochaic tetrameter XRXR (which is formally quite similar to the Spanish original inasmuch as the presence of rhyme compensates for the absence of assonance) is strongly associated with the poetry of Heinrich Heine. These additional associations make it more difficult to use this form to translate and imitate Romancero verse.

I must therefore discuss the interactions among three national poetic traditions: the Spanish tradition as the source culture, the German tradition as an intermediary culture, and the Russian tradition as the target culture. I will also show that the conventional view of Russian-Spanish literary relations, which only takes into account German literary mediation in the 1790s-1830s (without considering the German influence in the 1840s and later) is inadequate. The foregrounding of the romance genre was a side effect of the Heine cult and thus should not be disregarded.

This study examines two key concepts. One is the semantic halo of meter, which assumes the existence of mechanisms through which the elements of verse form become associated with particular meanings and acquire the ability to bear specific semantic connotations. The other one is the concept of functional and formal equivalence in poetic translation. 
Russian verse theorists have been discussing the connection between verse rhythm and semantics since the 1910s (see Shapir 2015: 395-404; Trunin 2017: 41-48). Osip Brik in the late 1920s and Roman Jakobson in the late 1930s used the example of Russian trochaic pentameter to substantiate the idea that meter can assume a meaning of its own. This problem attracted broader attention after the publication of Kirill Taranovsky's article entitled "On the Relationships between Verse Rhythm and Theme”, where he expanded on his predecessors' observations by analyzing the semantics of trochaic pentameter in Russian poems written from the 1840s to the 1940s (see Taranovsky 1963). In the 1970s, Mikhail L. Gasparov started referring to this phenomenon as the "semantic halo" of meter. He contributed more than any other scholar to the study of semantic halos in Russian poetry (Gasparov 1999). Grigorii Vinokur, Miroslav Červenka, Mihhail Lotman, Marina Tarlinskaja, Maksim I. Shapir and other scholars, who examined the issue of semiotics of meter and analyzed distinctive prosodic features in the versification of particular authors and periods, as well as polymetrical poems, described various groups of meters as "semantically loaded systems of verse forms" (see Pilshchikov 2017: 57). A study of the formation of verse semantics should also account for the semantization of traditional stanzaic forms in Russian poetry (see, e. g., Shapir 2015: 257-323; Stepanov 2010; Belousova 2013).

Eugene A. Nida (1964: 166-177) proposed a dichotomy of functional (dynamic) vs. formal equivalence that refers to the differences between the translation and the original. Russian scholars discussed the functional principle as the foundation for judgment on the adequacy of translations and on the best accessible ways of rendering the formal structure of the original. One of them was Andrei V. Fedorov, who began his work under the supervision of Yuri Tynianov (Pilshchikov 2016: 71-72). In his article "The Sound Form of the Verse Translation (Problems of Metrics and Phonetics)", Fedorov considered, among other things, the issues of rendering rhythmic structure, functional equivalence, functional adequacy, and equivalent associations in translated poetic texts (see Fedorov 1928). Four decades later, in his article "Verse and Translation (From the History of the Romantic Poem)", Viktor Zhirmunsky came to the conclusion that "creative transformation of a foreign-language original" follows two paths, which "sometimes go in opposite directions and sometimes intersect"

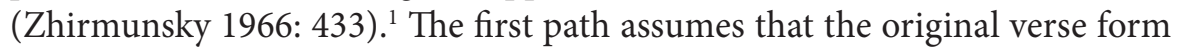
should be replaced by its functional equivalent in the national tradition of the target culture. The second path is based on the idea that the original verse form should be reproduced faithfully, as one of the constitutive features of the original's

1 Henceforth all translations from languages other than English are mine. 
genre and style. A great number of intermediate cases lie between these antithetical tendencies. ${ }^{2}$ These cases can be plotted as points on an imaginary axis with functionally equivalent translations at one end and formally equivalent translations at the other. For instance, functional equivalents can correspond to a certain extent to the formal characteristics of the original. Some of them prove to be more "precise", i. e., more adequate not only in view of their position in the poetic system, but also in view of the particulars of their verse form (line length, syntactic organization of stanzas, rhyme scheme, etc.). For instance, in Russian poetry both trochaic tetrameter and three-ictic dolnik (either isosyllabic or non-isosyllabic) can serve as functional equivalents of the Spanish octosyllabic romance meter, but dolnik is closer to romance verse in terms of its rhythmical structure. ${ }^{3}$ The question "what is the formal equivalent of original verse?" can be answered in more that one way. The material discussed here illustrates this fundamental problem and shows the historical instability of the relations between formal and functional equivalence.

The relationship between meter and meaning has always had a historical nature: the use of a particular verse form often entails "the use of the semantics (i. e. the thematic peculiarities) of the original" (Levin 1982: 152). This process did not go unnoticed by the scholars of metrical semantics. Yuri I. Levin maintains that a meter that a meter as a code "begins to predetermine lexical or syntactic content, becomes 'genrified' and acquires features of an 'emblem' or 'subtitle', while the 'code + meaning' complex turns into a canon or template" (Levin 1982: 152). It should be emphasized that all elements "at all levels of verse structure" are subject to "replication, i. e., metrization and semiotization" (Shapir 2000: 107) and, eventually, semantization. This article is focused primarily on the semantization of the clausula pattern. "Meter" can be understood in several different ways. It indicates the length of the line as well as other features of the prosodic structure: the presence $v s$. absence of rhymes, rhyme scheme, the linegrouping principle, etc. - including the clausula pattern. ${ }^{4}$ Therefore, there is no obstacle to using the concept of the "semantic halo of meter" here.

2 For a detailed typology of the methods of poetic translation (10 types) see Lotman 2012: $448-453$.

3 According to the nomenclature of Spanish meters proposed by Sergei Goncharenko (1988; cf. Domínguez Capparós 2014: 159-162). For a more detailed discussion of the metrical interpretation of the romance meter see $\$ 2$ of this article. 'Dolnik' is the Russian term that describes a particular type of non-syllabic-accentual meter, in which inter-ictic intervals are variable and can be either monosyllabic or disyllabic.

4 Meter, in a broad sense, is conceived of as "a sum total of constant paradigmatic segmentations [...] that allows one to predict the structure of each following verse line" (Shapir 2000: 83). 


\subsection{Material}

For this paper, I examined the Russian translations of poems written in Spanish romance verse. This includes translations of folk and literary Spanish romances, folk songs and the romance passages from Spanish dramas and Spanish polymetrical Romantic poetry. I also analyzed imitations of Spanish romances and poems with "Spanish" semantic leitmotifs written in either unrhymed trochaic tetrameter or trochaic tetrameter, in which the second and the fourth lines are rhymed but the first and the third remain unrhymed. I did not analyze imitations of Spanish romances that use other metrical forms. German and English translations of romances and numerous poems in these languages in unrhymed or half-rhymed ${ }^{5}$ trochaic tetrameter were only analyzed as a necessary background and the most probable intermediaries between the Spanish and Russian texts.

\section{3. "Spanish trochees" and other equivalents of Romancero verse in Russian poetry: a survey of previous scholarship}

Verse forms used in Russian translations of Spanish romances and their imitations have never been studied specifically. Mikhail P. Alekseev (1985: 5-205, 240-257) wrote a history of translations (more detailed for the period between 1789 and 1835 and somewhat sketchy for the period between 1835 and the 1860s) in the broad context of Spanish-Russian cultural relations and accompanied his analysis with some prosodic observations. Vsevolod Bagno commented on the clausula scheme in the first Russian translations of Spanish romances (Bagno 2006: 98-100). Efim Etkind (1999: 57-59) briefly discussed the variety of clausula patterns in connection with Alexander Pushkin's attempts at the Spanish romance genre in the 1830s and the style of the Russian Romancero. M. L. Gasparov (2000/1984: 69, 121, 176-177; 1999: 194, 200$201,205)$ mentioned "Spanish trochees" as one of the more exotic domains of Russian unrhymed trochee's semantic evolution. He also emphasized the influence of German poetry on the use of unrhymed trochaic tetrameter in Russian lyrics of the 1840s-1880s and noted that the German Romantics had borrowed this type of verse from Spanish romances (Gasparov 2000/1984: 176).

Translators also contributed to the discussion of the equivalents of assonance. Mikhail Donskoy described his search for the Russian equivalent of Spanish assonance in translations of Spanish dramas (Donskoy 1970:

\footnotetext{
5 Trochaic tetrameter rhyming on even lines.
} 
212-216). Some comments on the verse forms of the Russian translations of Romancero are found in an essay on the fate of Spanish poetry in Russia by Sergei Goncharenko (1978: 21-29). In her dissertation (supervised by Goncharenko), Asja Kopina analyzed the structural and functional differences between Spanish and Russian rhymes and systematized the way that Spanish assonance is rendered in Russian translations (Kopina 2001). Irina Ershova (2014) criticized the Russian tradition of translating old Spanish romances for their stylistic and formal differences from the original texts.

I have previously discussed some aspects of the rendition of romance verse in Konstantin Balmont's translations of Pedro Calderón de la Barca’s dramas and Spanish folk songs in Polilova 2013 and 2014 (see also Bagno 2005: 144-152). Unrhymed trochaic tetrameter FFFm, used by Alexander Blok and Anna Akhmatova in 1913 and 1914 (see $\$ 3.4$ below), attracted the attention of Michael Wachtel (2006) and Alexander Zholkovsky (2009/2006). These scholars independently investigated the origins of this version of "Spanish trochee" in Blok's poetry. Wachtel focused on this problem in connection with the "poetic dialogue" between Blok and Akhmatova. Zholkovsky examined Akhmatova's subsequent use of this meter; he also made important observations on "Spanish trochee" with satirical overtones. Elsewhere (Polilova 2017) I have pointed to Balmont's 1903 poem "Nezhnyj zhemchug, Margarita..." ("Gentle pearls, Margarita...") as Blok's plausible source and surmised that Blok had borrowed Balmont's meter. In this study I develop my earlier observations in a broader context of the evolution of Russian verse.

\subsection{Structure of the article}

This paper is organized as follows: Section 2 describes the structure of Spanish romance verse, focusing on the structural features that are most important for my topic, and briefly outlines the reception of romance as a metrical form in Germany and England. Section 3 discusses the process by which Romancero and the so-called "Spanish trochee" entered Russian poetry, then points out the elements of romance verse chosen by translators and poets, and examines how these competing forms correspond, formally and functionally, to the original. In the same section I also clarify the role that translations of Heine's poetry played in the establishment of the mock Hispanicized romance genre. Finally, I analyze in detail the process by which the FFFm clausula pattern came to be associated with "Spanish" themes outside the trochaic meter. 


\section{The metrical form of romance and its interpretations}

\subsection{The Spanish romance as an international verse form}

The scholarly literature on the Romancero genre - its origin, formal scope, metrical and rhythmical structure - is extensive, and the number of controversies it has ignited is perhaps only comparable to debates over the Cantar de mío Cid. ${ }^{6}$ I will focus on this genre's general metrical form, which will be sufficient for this article's purposes.

The word Romancero denotes any collection of Spanish short narrative poems or ballads of folkloric or literary provenance, fragmentary in character, composed of eight-syllable lines (with feminine endings) or seven-syllable lines (with masculine endings); in these line sequences, the even-numbered lines are assonant and the odd lines remain unrhymed. ${ }^{7}$ Compare the opening lines of the romance "Abenámar y el rey don Juan" ("Abenámar and King John”) assonating in í-a:

$\begin{array}{lll}\text { - ¡A Abenámar, Abenámar, } & {[\mathrm{X}] \quad \cup \cup 3 \cup \cup \cup 7 \cup} \\ \text { moro de la morería, } & {[\mathrm{A}] \quad 1 \cup \cup \cup \cup \cup 7 \cup} \\ \text { el día que tú naciste } & {[\mathrm{X}] \quad \cup 2 \cup \cup \cup \cup 7 \cup} \\ \text { grandes señales había! } & {[\mathrm{A}] \quad 1 \cup \cup 4 \cup \cup 7 \cup} \\ \text { Estaba la mar en calma, } & {[\mathrm{X}] \quad \cup 2 \cup \cup 5 \cup 7 \cup} \\ \text { la luna^estaba crecida; } & {[\mathrm{A}] \cup 2 \cup 4 \cup \cup 7 \cup} \\ \text { moro que^en tal signo nace, } & {[\mathrm{X}] \quad 1 \cup \cup \cup 5 \cup 7 \cup} \\ \text { no debe decir mentira. } & {[\mathrm{A}] \quad \cup 2 \cup \cup 5 \cup 7 \cup}\end{array}$

A typical text contains 25 to 80 lines and consists of a tirade (Spanish: tirada; French: laisse monorime) - a series of lines, in which the even-numbered ones assonate (XAXA...). In the example above, the following words assonate: morería: había: crecida : mentira. The two last vowels at the end of each even line are to be the same, but the consonants are to differ.

In Spanish versification, paroxytones (Spanish: llanas) assonate in two vowels (or a diphthong), while oxytones (Spanish: agudas) assonate on the

6 For more on the subject, see the bibliographies: Domínguez Caparrós 1988; Micó 2009.

7 Historically: assonanced lines of sixteen syllables, divided into hemistichs of eight syllables. 
last syllable only (asonancia aguda). The post-tonic vowels do not have to be completely identical: a relative proximity in place of articulation suffices (i for e, u for o; Spanish: asonancia equivalente, asonancia simulada). There exist 20 possible simple assonances (ignoring diphthongs and vocal articulation similarity): á, ó, é, í, ú, á-a, á-e, á-o, é-a, é-e, é-o, ó-a, ó-e, ó-o, í-a, í-e, í-o, ú-a, ú-e, and ú-o. According to various accounts, in old romances the proportion of asonancia aguda (i. e., masculine endings) is about $20 \%$, and in literary romances about 15\% (Navarro Tomás 1983: 238, n. 40; Kopina 2001: 139, table 1).

In Spanish poetry, assonance occupies a special place. Its function is significantly different from that of assonance in other forms of European poetry. First of all, the opposition between assonance (inexact rhyme) and consonance (perfect rhyme) corresponds to the opposition between two dissimilar poetic registers - the folkloric register (assonance) and the literary register (perfect rhymes). The former is mostly represented by romance verse, and the latter by various stanzas. In the versification of the Golden Age drama and the polymetrical poems of the Spanish Romantics, these two registers are interrelated and their combination is especially expressive. Spanish assonance is essentially a very simple type of rhyme, which abounds in the language and demands almost no creative effort from the poet. Therefore the Spanish poet's task seems as if intentionally complicated by the requirement of multiple repetitions of the same assonating vowels throughout the poem.

\subsection{The interlingual transfer of Spanish assonance and the romance meter}

Russian and Spanish assonance differ in formal structure and functions (Zhirmunsky 1975: 287; Kopina 2001: 56-66). In Spanish, the absence of vowel reduction allows the listener and reader to perceive assonance when consonants are quite different. Russian assonance, due to the significant reduction and transformation of both pre-tonic and post-tonic vowels, is not sensitive to vowels in rhymed syllables except the last ictus (the stressed vowel of the rhyme). The role of consonants in Russian assonance is therefore very important: Russian assonance permits and even requires a certain difference in the consonant rhyme sets, but at the same time alleviates it. According to Asja Kopina, "in Russian assonance, the total number of rhyming consonants normally exceeds the number of consonants in a classical perfect rhyme" (Kopina 2001: 65-66). Moreover, Russian assonance is a "difficult" and experimental kind of rhyme. Compare: zabúdem : ljúdi, stúzhe : krúzhev, bezmólvny: vólny, opúshchen : grjadúshhem, skrómnyj : napómnil, kúpol: slúshal (examples from Zhirmunsky 1975: 287-288). Furthermore, when writing in Russian, it is hard 
to maintain a monorhyme, i. e. multiple repetitions of the same vowels in the rhyme. However, when this requirement is fulfilled (see the experimental translation of Cantar de mío Cid into Russian made by Boris Yarkho in the 1930s and his unpublished translations of Spanish romances), the feminine clausulae do not reproduce double assonance (as was already noted above, Spanish prosody requires the coincidence of two vowels or at least some similarity between them). In Russian experimental assonance, only the stressed vowel is repeated, while the post-tonic vowel varies: plácha : paláty: nástezzh: plát’jạ : slinjávshịh : pecháli : slovámí : sláva : supostáty (Yarkho 1936: 362). This type of assonance remains unnoticed by Russian readers because they have no experience of this type of euphony in their native tradition.

We may distinguish three solutions used in the Russian tradition:

1) omission of assonance;

2) experimental imitation of assonance;

3) substitution of Spanish assonance either by classical rhymes or inexact rhymes (single-vowel assonance with additional rhyming consonants).

In the German tradition, as I will show below, the same three approaches already coexisted in the late eighteenth and early nineteenth centuries. In Russia, the first attempts to substitute rhyme in translation for original Spanish assonance date back to the 1880 s, while attempts to imitate assonance experimentally occurred as late as the 1930s. In Germany, thanks to the Romantics, double assonance of the Spanish type became widespread not only in translations from Spanish but also in original German poems (Knörrich 2005: 16).

Scholars have proposed different interpretations of the rhythm of romance verse. It has been described as traditional octosyllabic verse, as three-ictic dolnik (Goncharenko 1988: 48-49), or as a specific type of trochaic tetrameter with rhythmic licencia in the first half of each line (Bělič 1969; Jandová 1984). In his classification of Spanish versification systems, Domínguez Caparrós (2014) places medieval romance verse in the group referred to as verso fluctuante (i. e., verse in which the number of syllables oscillates within a certain range) ${ }^{8}$

In the late eighteenth and early nineteenth centuries, when romance became a point of interest in Europe, its rhythm was interpreted as trochaic. As early as 1834, in August Apel's Metrik, trochaic tetrameter was referred to as the meter "of Spanish romance and Spanish drama" (Apel 1834: 322).

8 “[...] su número de sílabas oscila, dentro de unos límites [...]" (Domínguez Caparrós 2014: 159). 
In 1780, Friedrich Justin Bertuch used trochaic tetrameters in FmFm quatrains of his "Romanze vom Grafen Guarinos". He substituted exact rhymes for original Spanish assonance:

Weh und bitter, ach Franzosen,

$[\mathrm{X}][\mathrm{F}]$

War die Jagd bey Ronceval!

$[\mathrm{R}][\mathrm{m}]$

Carlomann verlohr, mit Ehre,

[X] $[\mathrm{F}]$

Seine zwölf Pairs allzumal.

[R] [m]

Johann Gottfried Herder, in his first translations of Spanish romances included in Volkslieder (1778) - "Zaid und Zaida", "Zaida an Zaid", "Zaid an Zaida", "Zaida’s traurige Hochzeit" ("Zaida’s Unhappy Marriage"), "Die Herrlichkeit Granada's" ("Granada's Splendor"), ${ }^{9}$ "Abenamars unglückliche Liebe" ("Abenamar's Unfortunate Love"), ${ }^{10}$ etc. - used unrhymed quatrains ${ }^{11}$ with feminine endings:

\section{Zaid und Zaida}

Durch die Strasse seiner Dame $[\mathrm{F}]$

Wandelt Zaid auf und nieder,

Harrend, daß die Stunde komme,

Endlich komme, sie zu sprechen.

\section{Zaida's traurige Hochzeit}

Und in dieser Nacht vermählet

Sie sich einem schlechten Mohren,

Weil er reich und in Sevilla

War Alcaide von Alcazar.

Die Herrlichkeit Granada's

Abenamar, Abenamar!

Mohr aus diesem Mohrenlande,

\footnotetext{
9 The texts of the romances were taken from Ginés Pérez de Hita's Historia de los vandos de los zegries y abencerrages caualleros moros de Granada (1595).

10 A romance taken from Cancionero de Romances (around 1550).

11 Both "Zaida’s traurige Hochzeit" and "Die Herrlichkeit Granadas" contain one 6-line stanza alongside with the quatrains.
} 
Jener Tag, der dich gebohren,

Hatte schöne große Zeichen...

In the romance poem "Alkanzor und Zaida", also included in this collection - a translation of "Alcanzor and Zayda, a Moorish Tale: Imitated from the Spanish"12 from the Reliques of Ancient English Poetry collected by Bishop Thomas Percy (1765) - Herder followed the structure of the English original and used half-rhymed trochaic tetrameter XRXR with alternating feminine and masculine rhymes FmFm:

In yon palace lives fair Zaida,

$[\mathrm{X}][\mathrm{F}]$

Whom he loves with flame so pure:

[R] [m]

Loveliest she of Moorish ladies?

$[\mathrm{X}][\mathrm{F}]$

He a young and noble Moor.

[R] [m]

In dem Pallast wohnet Zaida,

[X] [F]

Die so treu, er sich erkohr,

[R] [m]

Sie, die schönste junge Mohrin,

[X] [F]

Er, ein edler junger Mohr.

[R] [m]

In the first four texts of Herder's translations of romances of the Cid (Der Cid, 1805) we find unrhymed trochaic tetrameter with the new clausula pattern FFFm:

$\begin{array}{ll}\text { Traurend tief saß Don Diego, } & {[\mathrm{F}]} \\ \text { Wohl war keiner je so traurig; } & {[\mathrm{F}]} \\ \text { Gramvoll dacht er Tag' und Nächte } & {[\mathrm{F}]} \\ \text { Nur an seines Hauses Schmach. } & {[\mathrm{m}]}\end{array}$

In the following romances, the text is divided not into quatrains but rather into stanzoids of different lengths, in which Herder makes the final verse catalectic, i. e. its masculine lines appear less frequently than once per four verses (F...m).

\footnotetext{
12 Percy made a free imitation of the romance "Zaide y Zaida" taken from the Historia de los vandos de los zegries y abencerrages caualleros moros de Granada: "In the following a wider compass hath been taken. The Spanish poem that was chiefly had in view [...]" (Percy 1910: 284). Herder included both a translation of this romance and a translation of its English imitation in his collection.
} 
It is difficult to determine what made Herder use the regular FFFm scheme and then strophoids with final masculine ending in his translation of Spanish romance verse. In the original Spanish romance "Cuidando Diego Lainez..." ("Brooding Sat Diego Lainez..."), which consists of 72 lines, all the endings are feminine. In the other three romances there are only occasional masculine clausulae. It has been long established that Herder based his romances of the Cid on the anonymous prosaic French paraphrase of the Cid cycle in the Parisian Bibliothèque universelle des romans (1783) and consulted the Spanish originals only at the last stage of his work. The stanza chosen by Herder does not formally correspond to the original. On the contrary, the regularized alternation of feminine and masculine clausulae and the abundance of masculine endings contradict the original. This contradiction is especially visible due to the repetitions of the structure (FFFm FFFm FFFm ...).

Nothing like this quatrain is found in the source text. The vast majority of the clausulae, as noted above, are feminine, and the series of the romance is not divided into quatrains. ${ }^{13}$ In the Spanish original, only one assonance is usually applied per rather long passages, containing tens of verses; therefore, the introduction of regular FFFm quatrains in the translation considerably restructures the Romancero form. Despite this formal contradiction, the stanza proposed by Herder - and the principle of combining catalectic and acatalectic lines of unrhymed trochaic tetrameter - deeply influenced the development of German verse. After Der Cid, Heinrich Heine used this variation of "Spanish trochees" with some differences (see $\$ 3$ of this article) in his mock-epic poem Atta Troll (1841-43). In his letter to the publisher, Baron Johann Georg von Cotta, dated 17 October 1842, Heine states he used Herder's Der Cid as a model. This form became associated with the names of both poets, Herder and Heine.

As can be seen from the above, in Germany, at the very first stage of translating Spanish romances, at least four formal equivalents were proposed to render their metrical form. These equivalents are similar in that they use trochaic tetrameter but different both in that they either render or do not render assonance and in the chosen clausula pattern.

In addition, German poets strove to integrate Spanish-style assonance into German poetry. In his translations of romance verse in Calderón's dramas, August W. Schlegel used assonance in a way that recalled the Spanish originals

\footnotetext{
13 I leave aside the possibilities of the strophic organization of the romances on the basis of quatrains (see Morley 1916), combination of consonance and assonance in romance verse (ibid.), and graphic division into stanzas (see Scherr 2016) in German, English and Russian translations of Spanish romances.
} 
(XAXA). For instance, in the first act of the play Die Andacht zum Kreuz (The Cross Devotion, 1803, a translation of Calderón's La devoción de la Cruz), assonance on é- $\mathrm{e}^{14}$ in the dialogue between Lisardo and Eusebio continues for more than 200 lines. Here is the beginning of Lisardo's speech:

\section{Lisardo}

Wohl, ich bin ein Sieneser

Des Lisardo Curcio Sohn.

Meines Vaters ungemeßner

Aufwand, hatt' in kurzem Zeitraum

Das Vermögen aufgezehret...
[A]

$[\mathrm{X}]$

$[\mathrm{A}]$

$[\mathrm{X}]$

[A]

Johann Diederich Gries, another German translator of Calderón, even copied the assonant vowels from the Spanish text in his translation of Calderón's $E l$ alcalde de Zalamea [The Mayor of Zalamea] (Der Richter von Zalamea, 1822):

\section{Inés}

Asómate a esa ventana,

prima - así el cielo te guarde -,

verás los soldados que entran

en el lugar.

\section{Isabel}

No me mandes

que a la ventana me ponga,

\section{Inés}

Mühmchen, komm ums Himmels willen, [X] Komm ans Fenster! Die Soldaten [A]

Sollst du sehn, die eben einziehn [X]

In den Ort.

\section{Isabel}

Nur nicht verlange,

Daß ich mich ans Fenster stelle,

\footnotetext{
14 In the Spanish original the assonance is on é-a: "Pues yo soy Lisardo, en Sena, / hijo de Lisardo Curcio. / Bien excusadas grandezas / de mi padre consumieron”.
} 
Wenn der Mensch dort auf- und abgeht. [A]

Denn du weißt, wie sehr mich 's ärgert, [X]

Ines, dort ihn zu gewahren.

$[\mathrm{A}]^{15}$

Another German author who used this type of assonance was Friedrich Schlegel in his tragedy Alarcos (1802). The German romance began to develop independently from the Spanish tradition, but continued to use its assonant rhymes. Zhirmunsky (1975: 397) points to similar experiments of another Romantic poet, Clemens Brentano's Die Romanzen vom Rosenkranz (Romances of the Rosary, 1812):

In des ernsten Tales Büschen

$[\mathrm{X}]$

Ist die Nachtigall entschlafen,

Mondenschein muß auch verblühen,

Wehet schon der Frühe Atem.

Heine also used this type of assonance (see an example in $\$ 3.2){ }^{16}$

German poetry also integrated other verse forms to represent the Spanish romance. For instance, Brentano, following Herder, used a regular combination of catalectic and acatalectic unrhymed trochees. In the romance poem "Nach Sevilla, nach Sevilla..." from the play Ponce de Leon (1804), a series of five feminine lines is followed by a masculine line - making for a total of six lines (FFFFFm):

$\begin{array}{ll}\text { Guten Abend, guten Abend - } & {[\mathrm{X}][\mathrm{F}]} \\ \text { Lieber Vater, setzt euch nieder, } & {[\mathrm{A}][\mathrm{F}]} \\ \text { Ei, wo seid ihr dann gewesen? } & {[\mathrm{B}][\mathrm{F}]} \\ \text { Und dann singt sie schöne Lieder, } & {[\mathrm{A}][\mathrm{F}]} \\ \text { Kann so hübsch in Büchern lesen, } & {[\mathrm{B}][\mathrm{F}]} \\ \text { Ach! und ist mein einzig Kind. } & {[\mathrm{X}][\mathrm{m}]}\end{array}$

The first and the last lines of this stanza remain unrhymed but in the middle there is a sequence rhymed $A B A B$.

15 Example from Darebný 2016: 114.

16 Zhirmunsky writes that these Romantic poets' experiments remained exotic because of linguistic features: "[D]espite the prosodic experiments of the Romantics, assonances remain an exotic genre in the German poetry due to the absence of sonorous clausulae (the post-tonic syllable always contains a reduced and vague e)" (Zhirmunsky 1975: 397). 
In terms of functional equivalence, all of the above-described German equivalents of romance verse are equally good. The use of trochee can be explained by the fact that it is common in folk songs. But in terms of formal equivalence, poets and translators found different solutions for rendering assonance. The solutions that retain the phonetic correspondence among even-numbered lines hew closer to the Spanish model. Unrhymed trochee with feminine clausulae wipes out assonance altogether.

Unrhymed trochees were by default associated with folk songs and quite naturally became a cultural signifier of the Spanish romance. However, both the regular FFFm pattern of unrhymed clausulae proposed by Herder and attempts by other Romantic poets to render assonance can be viewed as ways of creating a special form, distinguishable from verses with a general folkloric feel.

In English literature, as George W. Umphrey's study revealed, translators of Spanish romance use seven basic verse types (see Umphrey 1946). It is important for this study that one type (namely, the quatrains of trochaic tetrameters structured XRXR, first used by Percy in his translation of "Río verde, río verde..." ${ }^{17}$ and in his "Alcanzor and Zayda") was "frequently used as a model by many of the later translators" (Bryant 1973: 227).

The scope of the quasi-terminological expression "Spanish trochee" is often limited to blank (unrhymed) verse only (Gasparov 2000/1984: 69, 121, 176177). Yet it is evidently also correct to use it for trochaic tetrameters with either assonance in every second line (XAXA) or a classical rhyme in every second line (XRXR), which serve as a rough equivalent of the original assonance.

Columns 1-3 of Table 1 summarize the information presented above.

17 "Gentle river, gentle river, / Lo, thy streams are stain'd with gore, / Many a brave and noble captain / Floats along thy willow'd shore". 
Table 1. Clausula models in the translations of Spanish romances

\begin{tabular}{|c|c|c|c|c|}
\hline $\begin{array}{l}\text { Model } \\
\text { number }\end{array}$ & $\begin{array}{l}\text { Clausula } \\
\text { pattern }\end{array}$ & $\begin{array}{l}\text { German poets and } \\
\text { translators who } \\
\text { used this model }\end{array}$ & $\begin{array}{l}\text { Russian poets } \\
\text { and translators } \\
\text { who used this } \\
\text { model }\end{array}$ & $\begin{array}{l}\text { assonance } \\
\text { / rhyme }\end{array}$ \\
\hline I & $\mathrm{F}$ & Herder & $\begin{array}{l}\text { Likhonin } \\
\text { Almazov }\end{array}$ & \multirow[t]{4}{*}{ unrhymed } \\
\hline II & FFFm & Herder & Balmont & \\
\hline III & F...m & Herder & Zhukovsky & \\
\hline IV & FmFm & & $\begin{array}{l}\text { Karamzin } \\
\text { Katenin } \\
\text { Gonorsky }\end{array}$ & \\
\hline V & XRXR & $\begin{array}{l}\text { Bertuch } \\
\text { Herder }\end{array}$ & $\begin{array}{l}\text { Nemirovich- } \\
\text { Danchenko } \\
\text { Briusov }\end{array}$ & \multirow[t]{2}{*}{$\begin{array}{l}\text { assonanced } \\
\text { / rhymed }\end{array}$} \\
\hline VI & XAXA & $\begin{array}{l}\text { A. W. Schlegel } \\
\text { Gries }\end{array}$ & $\begin{array}{l}\text { Yarkho } \\
\text { Donskoy }\end{array}$ & \\
\hline
\end{tabular}

\section{Romancero and "Spanish trochee" in Russia and the influence of Heinrich Heine}

Russian interest in old Spanish romances emerged under the influence of German Romantic poets. The first stage of the evolution of this genre in Russia has been described thoroughly in scholarly literature (see Alekseev 1985: 84-85, 151-156, 240-257). The syllabic-accentual interpretation / transformation of the romance meter was also adopted from the German tradition. Unrhymed trochaic tetrameter with various clausula patterns became a verse form that was used to represent the original Spanish meter. It was initially used in translations, imitations, and pastiches, but later unrhymed trochaic tetrameter FFFm acquired some degree of autonomy in lyric poetry.

The use of trochaic verse was justified here from the perspective of functional equivalence, as in the German translations. The semantic range of Russian trochaic tetrameter, as described by Gasparov (2000/1984: 192-216), was strongly associated with the use of this meter in folk songs. This is one of the reasons why trochee was successfully exploited in Russian classical poetry in order to render a folkloric and exotic feel (Greco-Latin, Slavic, "Oriental", Scottish, and, of course, Spanish). 
For almost a hundred years, Spanish folk romances were mostly translated, both from intermediary texts and directly from the Spanish originals, using unrhymed trochaic tetrameter. Attempts to render assonance in translations of Spanish Romancero with an XRXR rhyme pattern (Model V) first appeared in Russian translations as late as the 1880s. In the 1930s, Boris Yarkho experimentally introduced assonance imitations (Model VI) in his translations. However, Model V with XRXR clausula pattern was introduced into Russian poetry much earlier, with no direct influence of romances, but rather thanks to Heine's popularity among Russian poets since the 1840s. In his poetry, various versions of "Spanish trochee" were used outside of translations - in imitations, stylizations, parodies and ballads even without an identifiably "Spanish" local color. Let us describe this process in more detail.

\subsection{The beginning: Nikolai Karamzin, Vasilii Zhukovsky and Pavel Katenin}

The first example of the use of "Spanish trochee" - and at the same time the first ballad written in Russian - is Nikolai Karamzin's romance poem "Graf Gvarinos" ("Count Guarinos"). The most important Russian pre-Romantic writer, Karamzin composed this poem in 1789 and published it in 1792. The romance was translated not from the Spanish original but from Friedrich Justin Bertuch's German version "Romanze vom Grafen Guarinos” (mentioned in $\$ 2.2$ ). In accordance with Bertuch's text, Karamzin used alternating trochees in FmFm quatrains - but, unlike Bertuch, he did not rhyme them (Model IV): $:^{18}$

$\begin{array}{ll}\text { Sólntsa svét pochtí zatmílsja } & {[\mathrm{F}]} \\ \text { Ot velíkogo chislá } & {[\mathrm{m}]} \\ \text { Tékh, kotórye stremílis' } & {[\mathrm{F}]} \\ \text { Na Gvarínosa vse vdrúg. } & {[\mathrm{m}]}\end{array}$

After Karamzin, "Spanish trochee" remained out of use for a long time. In 1816-18 Razumnik Gonorsky published two translations of the romances that until recently were entirely unknown (Korkonosenko 2018; Polilova,

\footnotetext{
18 The form of Karamzin's translation is discussed in Alekseev 1985: 244; Stephenson 1938: 105; and Nebel 1967: 104-105. These scholars do not emphasize the poet's formal innovation and describe the interaction between Karamzin's and Bertuch's romances in rather vague terms, so that most readers incorrectly assume that Karamzin both followed the German text and reproduced its form.
} 
forthcoming). Gonorsky also used unrhymed trochaic tetrameter FmFm. The first-rate Romantic poets Vasilii Zhukovsky and Pavel Katenin turned to Spanish material and started translating the Romances del Cid. Like Karamzin, they based their translations on the German version, Herder's Der Cid. It has been shown that Zhukovsky also consulted the Spanish text (Remorova 1989: 176 and sq.; Zhiljakova 2010). As noted above, Herder's German text uses unrhymed trochaic tetrameter with regular clausulae FFFm (Model II) and F...m trochaic tetrameter without strict clausula sequences but with predominantly feminine clausulae (Model III). Zhukovsky did not copy the FFFm stanza, but used a free ordering of masculine and feminine clausulae. ${ }^{19}$ Yet it is easy to find some regularities in their distribution. For instance, in his translation of ten romances published in 1831, the ratio of $\mathrm{m}$-clausulae to F-clausulae is 334 to 35, i. e., a masculine clausula appears in every tenth line on average. Moreover, Zhukovsky often used masculine clausulae (and the clausula pattern FFFm) to mark the beginning and end of each romance. Romances III, IV, and VI begin as follows: FFFmFFFm $(F F F m \times 2)$. In Romance $V$, the FFFm pattern is repeated three times (FFFm $\times 3$ ). Romances III, IV, V, VI, VII, VIII, and IX end in masculine clausulae.

To render romance verse, Katenin, in his turn, used the same model as Karamzin - namely, unrhymed trochaic tetrameters with alternating FmFm clausulae:

Dón Diég sidél pechál'nyj,

Vvék niktó tak ne stradál.

Grústno dúmal dnếm i nóch'ju,

Chto egó porúgan dóm...

(1822-1823, published in 1832)
$[\mathrm{F}]$

$[\mathrm{m}]$

$[\mathrm{F}]$

$[\mathrm{m}]$

The greatest Russian poet Alexander Pushkin chose the same FmFm pattern in his imitation of Spanish romances, "Na Ispaniju rodnuju..." ("To his native Spain...", 1835). Scholars believe that Pushkin used the first two cantos of Robert Southey's poem "Roderick, the Last of the Goths" (1814), written in iambic pentameter, as one of his sources of inspiration. However, Pushkin

19 Hereinafter I discuss Zhukovsky's Otryvki iz ispanskikh romansov o Side (Fragments from the Spanish Romances of the Cid), composed and published in 1831. In 1820, Zhukovsky translated seventeen other romances under the title Sid v pravlenie Ferdinanda (The Cid in Ferdinand's Reign). He followed Herder's texts and copied their stanzaic structure. These translations remained unpublished until 1978 (see Remorova 1989: 161-177). 
did not reproduce the metrical form proposed by Southey, but preferred the model already canonized in Russian translations.

Mikhail Likhonin, the first Russian translator who turned to the original Spanish text of the Romances del Cid, used trochaic tetrameter with uniform feminine clausulae (Model I) in his translation (1846). He possibly followed Herder or was encouraged by Zhukovsky's "Alonzo" (1831). ${ }^{20}$ In the 1870, Boris N. Almazov also translated the old Spanish romances about King Rodrigo with continuous feminine endings ("Korol' Rodrigo").

Thus, Russian poets initially used only those metrical models that do not render original Spanish assonance.

Column 4 of Table 1 summarizes the information presented above.

\subsection{From translations to imitations. Heinrich Heine and Russian poets}

The 1840s marked a new stage in the Russian use of "Spanish trochee". After Pushkin and Zhukovsky, this meter, which originated in Spanish translations, started to be used in free variations on "Spanish" themes. On the other hand, the new wave of German influence began at this moment.

M. L. Gasparov accurately described the trend of using trochaic tetrameter in the 1840s-1880s:

Next to the revival of the folkloric tradition of trochaic tetrameter, a renewal of another, Western tradition [of this meter] took place: philosophical lyrics [...] died away, and ironic lyrics came to dominate, modelled on the example of Heine, who was extremely popular in Russia at that time. It is from his lyrical poetry that trochaic tetrameter with feminine endings, either fully rhymed or half-rhymed [...], adopted by German Romantics from Spanish romances, entered Russian poetry. All this provided the new variation of the meter with an exclusive range of thematic associations; it contained both antiquity and modernity, both ingenuous lyricism and impressionistic negligence, as well as sophisticated irony. The Russian reader could hear in it the echoes of the romance trochee, the ballad trochee and the trochee of satirical songs. (Gasparov 2000/1984: 176)

20 A translation of Ludwig Uhland's Durand. 
Having mastered nearly all variations of this form proposed by the Romantics, ${ }^{21}$ Heine started adding irony and burlesque into the Romancero genre. Let us point out some examples of Heine's use of the metrical form in question.

In his Buch der Lieder (Book of Songs, 1827), Heine included a section of Romanzen, which contains, among others, a poem entitled Don Ramiro. In this poem, Heine used the Romanzenstrophe XAXA with feminine endings (Model VI):

Donna Clara! Donna Clara!

Heißgeliebte langer Jahre!

Hast beschlossen mein Verderben,

Und beschlossen ohn Erbarmen.
$[\mathrm{X}]$

$[\mathrm{A}]$

$[\mathrm{X}]$

[A]

In "Auf den Wällen Salamankas..." ("On the walls of Salamanca..."), another "Spanish" poem from this collection, Heine substituted rhyme for assonance (Model V) and used feminine endings throughout the text:

$\begin{array}{ll}\text { Auf den Wällen Salamankas } & {[\mathrm{X}]} \\ \text { Sind die Lüfte lind und labend; } & {[\mathrm{R}]} \\ \text { Dort, mit meiner holden Donna, } & {[\mathrm{X}]} \\ \text { Wandle ich am Sommerabend. } & {[\mathrm{R}]}\end{array}$

In 1843, Heine published the first version of his mock-epic poem Atta Troll, also written in "Spanish trochees" - namely, in quatrains with predominantly feminine clausulae. At the same time, Heine's text contains a few lines (below $10 \%$ ) with masculine endings (especially where the line ends with Atta Troll's name). Unlike Herder's stanzas and stanzoids, such lines can occupy any place in a stanza. As was already noted, Heine himself named Herder's Der Cid as the source of this poem.

Über schwarzen Bärenundank!

$[\mathrm{F}]$

Denn er habe Atta Troll

Stets wie einen Freund behandelt

$[\mathrm{F}]$

Und im Tanzen unterrichtet. of varying feet $(4 / 3 / 4 / 3)$. I leave these examples out of consideration. 
Ironic and grim romances written in trochee, some of them with "Spanish" settings and motifs, are also found in the main collection of Heine's poems, Romanzero (1851) - see "Der Mohrenkönig" (“The Moorish King”), "Spanische Atriden", "Vitzliputzli". In these, he combines his lyricism with sarcasm.

All these forms of trochee became associated with Heine's name. In the 1840 s and 1850s, Heine's influence was so strong that all the metrical forms discussed above - in connection with the Spanish Romancero - grew to be strongly associated with his poetry. This is especially true, of course, of the rhymed XAXA quatrains, which came to be known in Russia as "Heine's stanza". 22

Thus, through the love of Heine, the second wave of fascination with "Spanish trochee" came to Russia. This time, it had at most a vague connection with its remote Spanish sources.

In 1847, Afanasii Fet, the best lyricist of the new generation, translated the above-quoted poem "Auf den Wällen Salamankas...", retaining the feminine clausulae and rhyming even lines:

Po bul'váram Salamánki

Vózdukh blagorastvorénnyj.

Tám, v prokhládnyj létnij vécher,

Ja guljáju s míloj dónnoj.
$[\mathrm{F}]$

$[\mathrm{R}]$

It is possible that Nikolai Shcherbina wrote his poem "Noch' i sinora" ("The Night and a Signora", 1841), in unrhymed trochees with regular FFm clausulae, under the influence of the German tradition. The finale of this poem reads as follows:

$\begin{array}{ll}\text { Ó, sojdí ko mné v gondólu, } & {[\mathrm{F}]} \\ \text { Na razdól'e iz palátstso, } & {[\mathrm{F}]} \\ \text { Chernoókaja krasá! } & {[\mathrm{m}]} \\ \text { Ja ne búdu ljubovát’sja } & {[\mathrm{F}]} \\ \text { Étoj dévstvennoju nóch'ju!.. } & {[\mathrm{F}]} \\ \text { Ó, sojdí zh ko mné, sojdí!.. } & {[\mathrm{m}]}\end{array}$

Shcherbina's imitation of a certain southern European (most likely, Italian) charm seems to take the form of parody.

\footnotetext{
22 Vyacheslav V. Ivanov wrote that "the hundred years from Tiutchev and Lermontov to Blok passed under the sign of Heine [...]. His favorite meters were introduced to Russian poetry thanks to his influence" (Ivanov 2003: 490). Russian poets were especially affected by his "fascination [...] with even-rhymed or blank verse" (Ivanov 2003: 496; see also Iliushin 2004 86-87; Dubovskaja 1997: 98-135).
} 
According to Mikhail P. Alekseev (1985: 201-202), Russian poems satirizing clichéd compositions on "Spanish" themes - including the best known text of this kind, "Osada Pamby" ("The Siege of Pamba", 1854) by Kozma Prutkov (a parodic author created by Aleksei K. Tolstoy and the Zemchuzhnikov brothers) - were written as a response to the many hackneyed poems with exotic "Spanish" settings and plots, as well as the popularity of Vasilii Botkin's essay series Pis'ma ob Ispanii (Letters about Spain, in print since 1847). "The Siege of Pamba" is written in trochees with predominant feminine clausulae. Commentators on Prutkov's works rightfully point to Zhukovsky's Sid that introduced this clausula pattern in Russia and Katenin's Romansy $o$ Side (Romances of the Cid) as targets of Prutkov's parody (Berkov 1933: 76; Bukhshtab 1965: 432). Meanwhile, the fact that Prutkov's device of using comic, satirical, ironical and mock-sublime poetic genres in the form of Spanish romance was, in fact, borrowed from Heine, has gone unnoticed. Heine, who is often called "Germany's last Romantic", exploited this device in his mock-epic Atta Troll, as well as in "Pomare", "Vitzliputzli" and "Spanische Atriden". Prutkov's text is concurrently a kind of response to Heine and his Russian followers. It seems that "The Siege of Pamba" is much more closely connected with the reception of Heine's poetry and style than with the Russian literary process or the translations of romances about the Cid published in the first half of the nineteenth century. Heine played with the German Romantic tradition, and challenged established genres. Prutkov, following Heine, played with the Russian Romantic tradition, parodying Zhukovsky, Katenin and Heine's Russian adherents. Perhaps it is not a coincidence that one can find links between the "The Siege of Pamba" and Heine's "Spanische Atriden". In both texts, the hero's name is Don Pedro and the Spanish saint Jacob is mentioned. I believe, however, that the creators of Kozma Prutkov had some other, unknown influences: the parody demonstrates familiarity with the whole subgenre of the Romancero fronterizo (frontier Romancero), romances about the siege ("Romance del cerco de Baeza" ["On the Siege of Baeza"], "Romance del moro de Antequera" ["The Moor from Antequera"] and others).

Subsequently, poets used various types of Russian equivalents of romance verse for ironical and satirical poems. Yuri Verkhovsky, a learned and talented poet, translator and literary critic, combined catalectic and acatalectic lines of unrhymed trochaic tetrameter in his cycle of four poems published under the title "Romansy o grafe Villamediane" ("Romances about Count Villamediana", 1906) ${ }^{23}$ Sasha Cherny, a highly popular satirical poet, adopted

23 Verkhovsky used the following clausula patterns: 1) FFFm $\times 4$ FFFF; 2) FFFF/FmFm $\times 2$; 3) $\mathrm{AbAb} \times 4$ (assonance and inexact rhymes); 4) FFFF/FFFm $\times 2$ FFFF. 
the model with continuous feminine endings ("O, ispanets blagorodnyj!..” [“O, noble Spaniard!..”], 1906).

In the 1860s, under Heine's influence, Russian authors wrote several poems and ballads in unrhymed XRXR trochaic tetrameter; "Spanish" overtones in such compositions were one of the many possible themes. Vivid examples of such poems include Apollon Maykov's "Ispoved' korolevy" ("Queen's Confession", 1860) and the "Spanish Motifs" cycle by Vsevolod Krestovsky ("Ispanskie motivy", 1860).

The first translator to choose half-rhymed trochaic tetrameter XRXR to translate romances (rather than Heine's ballads) was Vasilii NemirovichDanchenko, the elder brother of the famous theater director Vladimir Nemirovich-Danchenko.

$\begin{array}{ll}\text { Na goré - suróvyj zámok; } & {[\mathrm{X}][\mathrm{F}]} \\ \text { Báshni, slóvno paladíny } & {[\mathrm{R}][\mathrm{F}]} \\ \text { V sérykh látakh, smótrjat grózno } & {[\mathrm{X}][\mathrm{F}]} \\ \begin{array}{ll}\text { V polusónnye dolíny. } & {[\mathrm{R}][\mathrm{F}]} \\ \text { ("Staryj zamok" [“The Old Casle"], 1888) }\end{array}\end{array}$

He also followed this model in his imitation of Romancero entitled "Korol' Ramiro" ("King Ramiro", 1889).

In the twentieth century, Konstantin Balmont used trochaic tetrameter with the XRXR rhyming scheme in his 1904 translations of Spanish coplas (see Polilova 2013: 150-151). Valerii Briusov also followed this model in his translation of the Spanish romance "Compañero, compañero..." ("Moj tovarishch! moj tovarishch!.." ["My companion, my companion!..”], 1913). Subsequently, many Soviet translators also used the XRXR pattern. However, this meter, with its strong association with Heine and its satirical connotations, proved utterly unfit for translating twentieth-century Spanish poets, above all García Lorca.

\subsection{Konstantin Balmont and the FFFm stanza}

Numerous studies have been devoted to the Hispaniana of the Russian Symbolist poet Konstantin Balmont (Azadovsky 2011; Polilova 2013, 2014; etc.). Here I only analyze the models he used to render romance verse in his translations. Since 1902, Balmont used a strict sequence of clausulae FFFm in his translations of Calderón's polymetric dramas.

Balmont consistently used unrhymed trochee only in two translations from Spanish (except for a few coplas noted above): first, in his translation of Tirso de Molina's drama El burlador de Sevilla (The Seducer of Sevilla) - Sevil'skij 
obol'stitel', which was not published in Balmont's lifetime; second, in his translations of fragments of romances from the Romacero General included in Balmont's comments to Liubov' i nenavist': Ispanskie narodnye pesni (Love and Hate: Spanish Folk Songs, 1911). In his other Spanish translations, Balmont used iambs instead of trochees and usually substituted unrhymed iambic tetrameter with three feminine clausulae and one masculine clausula for the romance verse of the original:

(I4FFFm)

Sebjá nevól'no voprosháju,

Chtò, són ja vízhu, probudívshis',

Il' rassuzhdáju usyplë́nnyj?

Ja srázu bódrstvuju i spljú.

$[\mathrm{m}]$

(Vrach' svoej chesti, 1912) ${ }^{24}$

The same meter and clausula sequence are found in Balmont's interpretation of Gongora’s romance "Servía en Orán al rey..." - "Ispanec iz Orana” ("A Spaniard from Orán”, 1902).

It may be suggested that the choice of verse with the FFFm clausula was the result of following Herder's example, as well as those of the most well known Russian romances discussed in $\$ 3.1$. One example is Zhukovsky's Sid, where unrhymed trochaic tetrameter with unregulated clausulae contains regulated fragments, including those with the FFFm clausula pattern.

Although this clausula sequence does not correspond to the original pattern, the FFFm pattern often reappears in Balmont's translations of Spanish poetry. Moreover, he began to combine it not only with binary meters (iambus and trochee) but also with ternary ones (dactyl, amphibrach, and anapaest). The earliest example is his Salamankskij student (The Student of Salamanca, 1919), a translation of José de Espronceda's polymetrical poem El estudiante de Salamanca. In his translation, Balmont used a combination of dactylic, amphibrachic, and anapaestic trimeters ${ }^{25}$ :

\footnotetext{
24 A translation of Calderón's El médico de su honra (The Surgeon of his Honor).

25 Salamankskij student was published for the first time only two years ago (see Espronceda 2015-2016).
} 
(D3FFFm)

Na kolokól'ne zabýtoj,

[F]

Vózle razrúshennoj tsérkvi,

Zvón voznikáet, proklját’ja,

[F]

Gólos anáfemy, zhút'.

[m]

(Am3FFFm)

Luná iz-za dál'nej vershíny

Vykhódit, ob"játa pechál'ju,

Edvá pripodnjáv nad ustúpom

$[\mathrm{F}]$

Cheló nezemnój belizný.

\section{(An3FFFm)}

Oshchutíl Montemár, chto grobnítsy

Sokrushílis' u nóg ego s tréskom,

Cherepá natolknúlis' na kámen',

I bezúmstvuet mërtvyj naród...

In terms of formal equivalence, only trochaic tetrameter and dactylic trimeter are isosyllabic to the original octosyllabic meter. In Spanish poetry, virtually no lines are based on repeated uniformity of syllabic-accentual feet, and the choice of a ternary meter over a binary one, as Sergei Goncharenko noted on a similar occasion, ${ }^{26}$ "cannot be, in fact, criticized": a line of the Spanish meter "mostly contains two ternary feet and one binary foot, a combination that is closest to the Russian dolnik verse, so that amphibrach [as well as dactyl and anapaest - V. P.] reproduces the sound of the original even better than trochee" (Goncharenko 1978: 22). One could even say that there is nothing surprising in the fact that Balmont (who had already allowed himself to occasionally use iambus, instead of the more traditional unrhymed trochee, to imitate Spanish verse) later turned to ternary meters as prosodic equivalents of octosyllabic Spanish verse. In all these cases, line length varies from seven to ten syllables, and the key signifier of romance verse is the clausula pattern FFFm. The metrical and rhythmical form of verse is of secondary importance.

\footnotetext{
26 Commenting on Dmitrii Oznobishin's decision to use amphibrach instead of the more usual trochee in his translation ("Al'gama", 1834) of the Spanish romance "Alhama".
} 


\subsection{Formation of the semantic halo of the FFFm stanza}

As I have tried to demonstrate above, in the first half of the nineteenth century, Russian poets, following Karamzin and the German Romantics, developed four models of rendering the original structure of Spanish romances in their translations and more or less faithful imitations. All these models use unrhymed trochaic tetrameter with different clausula patterns - FmFm, F, and F...m. Evenrhymed trochaic tetrameter was not used in translations of the Romancero until the 1880s. It was introduced into Russian lyrics in the 1840s due to Heine's influence and gradually became a form suitable for ballads and romances with exotic elements, as well as for various imitations of Heine's style. During the nineteenth century, the model with assonance (XAXA) was never used in translations. The first experiments of this type, dating back to the 1930s, were carried out by Boris Yarkho, a professional verse theorist of the formalist school.

The FFFm stanza, canonized by Herder as an equivalent form for Spanish trochees in the first four romances of Der Cid, was not adopted in Russia until the early twentieth century, when Balmont chose a regular FFFm clausula pattern for his translations of Spanish poetry (although Zhukovsky often used masculine clausulae to mark the beginning and end of each romance).

Balmont was also the first poet to introduce the stanza FFFm in combination with unrhymed trochaic tetrameter in his original lyrics. An example is his madrigal "Gentle pearls, Margarita..." (1903):

$\begin{array}{ll}\text { Nézhnyj zhémchug, Margaríta, - } & {[\mathrm{F}]} \\ \text { Kak pojút v ispánskikh pésnjakh, - } & {[\mathrm{F}]} \\ \text { Péli ángely na nébe } & {[\mathrm{F}]} \\ \text { V dén' rozhdén'ja tvoegó. } & {[\mathrm{m}]}\end{array}$

This text consists of four stanzas and reflects a direct influence of Spanish folk songs. This is indicated not only by the second line Kakpojút v ispánskikh pésnjakh ('As they sing in Spanish songs'), but also by each stanza of the poem; they are constructed as variations of Spanish folk coplas and reflect images typical of Spanish folk lyrics, for example, comparisons between lips and clove pinks and between eyes and heaven (Polilova 2013; Markov 1988: 194).

In conclusion, I will briefly discuss the history of the use of unrhymed FFFm clausulae in other poems of the Russian Silver Age, as well as the formation of this form's semantic halo.

In 1905, the FFFm stanza in combination with trochaic tetrameter was adopted by Alexander Blok in "Ty prokhodish' bez ulybki..." ("You walk by without a smile..."). In 1906 Yuri Verkhovsky used it in his semi-parodic cycle Romances about Count Villamediana discussed above (\$3.2). In 1913-14 it was 
finally canonized in the poetical dialogue between Blok and Anna Akhmatova (see Zhirmunsky 1970; Gasparov 1997: 489; Zholkovsky 2009/2006; Wachtel 2006; and Polilova 2017). In reply to Blok's madrigal "Krasota strashna, vam skazhut..." ("Beauty is terrible, they'll tell you..., December 1913), containing its Spanish motifs and addressed to Akhmatova, she composed "Ia prishla k poetu v gosti..." ("I came to the poet's house...", January 1914) that can be considered the most famous Russian poem that uses the FFFm stanza.

Later, Mikhail Kuzmin creatively transformed this structure by inserting two FFFm trochaic tetrameter stanzas (rhymed $\mathrm{ABCd} \mathrm{ABCd}$ and filled with quotations from Blok's "Beauty is terrible...") in his polymetrical poem "Byl by ja khudozhnik, napisal by..." ("If I were a painter, I would paint...", 1927; cf. Bogomolov 1996: 788).

I also found this clausula pattern beyond the scope of trochaic tetrameters in other poetical texts containing unambiguous "Spanish" associations. Compare three examples:

(1) Unrhymed trochaic trimeter FFFm. Marina Tsvetaeva's "Na zare moroznoj..." ("On the frosty dawn...") from the "Don Juan" cycle ("Don-Zhuan", February-May 1917):

Na zaré moróznoj

Pod shestój berếzoj

Za uglóm u tsérkvi

Zhdíte, Don-Zhuán...
$[\mathrm{F}]$

$[\mathrm{m}]$

(2) Unrhymed logaoedic verse $1^{\star} 2^{\star} 1^{\star}$ FFFm. Marina Tsvetaeva’s "Bozhestvenno, detski-plosko..." ("Divinely, childishly flat...") from the "Carmen" cycle (“Karmen", June 1917):

Bozhéstvenno, détski-plósko

Korótkoe, v sbórku, pláte.

Kak stórony piramídy

Ot pójasa mchát boká. $[\mathrm{m}]$

(3) Unrhymed iambic pentameter FFFm. Boris Poplavsky, "Liubov' k ispantsam" ("Love for Spaniards", 1920s):

Ispáncy éto vróde marokkáncev

Prekrásnejshie ljúdi na planéte

Oní davnó nosíli brjúki kléshem

Tren'-trén’kali na sábljakh v dóbryj chás. [m] 
Tsvetaeva may have copied this clausula scheme directly from Balmont's poetry. The two poets first met in June 1916 and soon became friends. In the summer of 1917 they met regularly to read poetry together (see Tsvetaeva's letter to Maksimilian Voloshin of 24 August 1917).

We can see that in Russia the FFFm stanza was first used in Balmont's translations of Spanish authors (combined with all syllabic-accentual meters), then in the original poems by Balmont, Blok, Verkhovsky, Akhmatova and Kuzmin (combined with trochaic tetrameter) and eventually in Tsvetaeva's poems (combined with various meters). As a result, the FFFm clausula pattern - an element of the metrical structure, which was proposed by Herder and had no formal correspondence with the original Spanish text - gradually became a signifier of the Spanish romance in Russian poetry. ${ }^{27}$

\section{References}

Alekseev, Mikhail Pavlovich 1985. Russkaja kul'tura i romanskij mir. Leningrad: Nauka.

Apel, August von 1834. Metrik. Bd. 1. Leipzig: Neue wohlfeile Ausgabe.

Azadovskij, Konstantin 2011. “Toledskoe predanie”: (Bal'mont - perevodchik Khose Sorril'i). In: Kul'turnyj palimpsest: Sbornik statej k 60-letiju V. E. Bagno. SanktPeterburg: Nauka, 6-21.

Bagno, Vsevolod Evgen’evich 2005. Russkaja poezija Serebrjanogo veka i romanskij mir. Sankt-Peterburg: Giperion, 144-152.

Bagno, Vsevolod Evgen'evich 2006. Rossija i Ispanija: obshchaja granitsa. SanktPeterburg: Nauka.

Bělič, Oldřich 1969. Sobre el ritmo de los romances españoles. In: Análisis estructural de textos hispanos. Madrid: Prensa Española, 1-18.

Belousova, Anastasija Sergeevna 2013. Genezis i evoljutsija russkoj oktavy. Unpublished Candidate $(\mathrm{PhD})$ dissertation, Russian State University for the Humanities, Moskva.

Berkov, Pavel Naumovich 1933. Koz'ma Prutkov: direktor Probirnoj Palatki i poet. $K$ istorii russkoj parodii. Leningrad: Izdatel'stvo AN SSSR.

27 Chapters 1 and 2 of this article result from the research project based at the Institute for World Culture of Lomonosov Moscow State University and supported by a Russian Science Foundation grant 17-18-01701. Chapter 3 of this publication was supported by the Grant of the President of Russian Federation for young scholars (grant no. MK-3319.2017.6). I am grateful to Igor Pilshchikov and Mikhail Oslon for their comments and suggestions. 
Bogomolov, Nikolaj Alekseevich 1996. Primechanija. In: Kuzmin, Mikhail. Stihotvorenija. Sankt-Peterburg: Akademicheskij proekt, 679-788.

Bryant, Shasta M. 1973. The Spanish Ballad in English. Lexington, KY: The University Press of Kentucky.

Bukhshtab, Boris Jakovlevich 1965: Primechanija. In: Prutkov, Koz'ma. Polnoe sobranie sochinenij. Moskva, Leningrad: Sovetskij pisatel', 419-462.

Červenka, Miroslav 2011. Smysl i stikh: Trudy po poetike. Perevod s cheshskogo A. Bobrakova-Timoshkina. Moskva: Jazyki slavjanskoj kul'tury.

Darebný, Jan 2016. Verso español y verso checo: traducción del teatro polimétrico de Calderón de la Barca. PhD dissertation, Masaryk University, Brno. https://is.muni.cz/th/v3gdn/Darebny_tesis.pdf (accessed 30.10.2018).

Donskoy, Mikhail 1970. Kak perevodit' stikhotvornuju klassicheskuju komediju? In: Masterstvo perevoda. [Vol. 7]. Moskva: Sovetskij pisatel', 186-216.

Domínguez Caparrós, José 1988. Contribución a la bibliografía de los últimos treinta años sobre la métrica española (Cuadernos bibliográficos 50). Madrid: Consejo Superior de Investigaciones Científicas.

Domínguez Caparrós, José 2014. Métrica española. Madrid: Universidad nacional de educación a distancia.

Dubrovskaja, Larisa Dmitrievna 1999. Polurifmovannyj stikh v russkoj pojezii pervoj poloviny XIX veka. Unpublished Candidate (PhD) dissertation, Herzen State Pedagogical University of Russia, Saint Petersburg.

Ershova, Irina Viktorovna 2014. Russkie perevody ispanskogo "starogo" romansa: razrushenie zhanra. In: Voprosy literatury 3, 148-161.

Espronceda, José de 2015-2016. Salamankskij student: Legenda. Perevod K. Bal'monta. Publikatsija T. V. Petrovoj, V. S. Polilovoj. In: Solnechnaja prjazha 9, 114-120; 10, 128-144.

Etkind, Efim Grigorjevich 1999. Bozhestvennyj glagol: Pushkin, prochitannyj v Rossii i vo Frantsii. Moskva: Jazyki slavjanskoj kul'tury.

Fedorov, Andrej Venediktovich 1928. Zvukovaja forma stikhotvornogo perevoda (Voprosy metriki i fonetiki). In: Poetika: Vremennik Otdela slovesnykh iskusstv Gosudarstvennogo instituta istorii iskusstv 4. Leningrad: Academia, 45-69.

Fowler, Rowena 1977. Comparative Metrics and Comparative Literature. In: Comparative Literature 29(4), 289-299. 
Gasparov, Mikhail Leonovich 1997. Stikh Anny Akhmatovoj. In his: Izbrannye trudy. Vol. III: O stikhe Moskva: Jazyki slavjanskoj kul'tury, 476-491.

Gasparov, Mikhail Leonovich 1999. Metr i smysl: Ob odnom iz mekhanizmov kul'turnoj pamjati. Moskva: RGGU.

Gasparov, Mikhail Leonovich 2000 [1984]. Ocherk istorii russkogo stikha: Metrika. Ritmika. Rifma. Strofika. [Second revised edition]. Moskva: Fortuna Limited.

Goncharenko, Sergej Filippovich 1978. Predislovie. In: Ispanskaja poezija v russkikh perevodakh. Moskva: Progress, 5-42.

Goncharenko, Sergej Fillipovich 1988. Stilisticheskij analiz ispanskogo stikhotvornogo teksta. Moskva: Vysshaja shkola.

Iliushin, Aleksandr Anatol'evich 2004. Russkoe stihoslozhenie. Moskva: Vysshaja shkola.

Ivanov, Vyacheslav Vsevolodovich 2003. Geine v Rossii. In his: Izbrannye trudy po semiotike i istorii kul'tury. Vol. 3. Moskva: Jazyki slavjanskoj kul'tury, 490-504.

Jandová, Jarmila 1984. El ritmo intensivo en los romances tradicionales colombianos. In: Thesaurus: Boletín del Instituto Caro y Cuervo 39, 270-310.

Knörrich, Otto 2005. Lexikon lyrischer Formen. Stuttgart: Kröner.

Kopina, Asja Evgenjevna 2001. Ispanskaja rifma v sopostavlenii s russkoj (strukturnosemanticheskij i funkcional'no-kommunikativnyj aspekty) i problemy perevoda ispanskogo rifmovannogo stikha na russkij jazyk. Unpublished Candidate (PhD) dissertation, Moscow State Linguistic University.

Korkonosenko, Kirill Sergeevich 2018. Rannij perevod s ispanskogo jazyka: romans “Zaid i Zaida” (1816). In: Russkaja literatura 1, 240.

Levin, Jurij Iosifovich 1982. Semanticheskij oreol metra s semioticheskoj tochki zrenija. In: Finitis duodecim lustris: Sbornik statej k 60-letiju prof. Ju. M. Lotmana. Tallinn: Eesti raamat, 151-154.

Lotman, Maria-Kristiina 2012. Equiprosodic translation method in Estonian poetry. In: Sign Systems Studies 40(3/4), 447-472.

Markov, Vladimir 1988. Kommentar zu den Dichtungen von K. D. Balmont, 1890-1909 (Bausteine zur Geschichte der Literatur bei den Slaven 31). Köln: Böhlau.

Micó, José María 2009. Bibliografía para una historia de las formas poéticas en España. Digital edition. Alicante: Biblioteca Virtual Miguel de Cervantes. www.biblioteca.org.ar/libros/140729.pdf (accessed 30.10.2018). 
Morley, S. Griswold 1916. Are the Spanish Romances Written in Quatrains? - and Other Questions. In: Romanic Review 7, 42-82.

Navarro Tomás, Tomás 1983. Métrica española: reseña histórica y descriptiva. Barcelona: Labor.

Nebel, Henry M. 1967. N. M. Karamzin: A Russian Sentimentalist. The Hague, Paris: Mouton and $\mathrm{C}^{\circ}$.

Nida, Eugene Albert 1964. Toward a Science of Translating: With Special Reference to Principles and Procedures Involved in Bible Translating. Leiden: E. J. Brill.

Percy, Thomas 1910. The Reliques of Ancient English Poetry. Collected by Bishop Thomas Percy. Vol. I. London: J. M. Dent \& sons, Ltd., and New York: E. P. Dutton \& co.

Pilshchikov, Igor 2016. The semiotics of phonetic translation. In: Studia Metrica et Poetica 3(1), 53-104.

Pilshchikov, Igor 2017. "The Inner Form of the Word" in Russian Formalist Theory. In: Mrugalski, Michał; Schahadat, Schamma (eds.), Theory of Literature as a Theory of the Arts and the Humanities (Wiener Slawistischer Almanach. Sonderband 92). Leipzig, Wien: Biblion Media, 37-64.

Polilova, Vera Sergeevna 2013. Ispanskie narodnye pesni v perevode K. Bal'monta. In: Vestnik Moskovskogo universiteta. Serija 9: Filologija 1, 147-161.

Polilova, Vera Sergeevna 2014. Polimetrija ispanskikh komedij Zolotogo veka i poeticheskij perevod: sluchaj Kal'derona v Rossii. In: Novyj filologicheskij vestnik 2, 88-98.

Polilova, Vera Sergeevna 2017. Belyj chetyrekhstopnyj khorej s okonchanijami ZhZhZhM: Bal'mont i razmer poeticheskoj perepiski Bloka i Akhmatovoj. In: Trudy Instituta russkogo jazyka imeni V. V. Vinogradova 11, 76-88.

Polilova, Vera Sergeevna (forthcoming). Dva mavritanskikh romansa v perevode R. T. Gonorskogo.

Remorova, Nina Borisovna 1989. V. A. Zhukovsky i nemetskie prosvetiteli. Tomsk: Izdatel'stvo Tomskogo universiteta.

Scherr, Barry P. 2016. To separate or not to separate: Stanza boundaries and poetic structure. In: Studia Metrica et Poetica 3(2), 32-49.

Shapir, Maksim Il'ich 2000. Universum versus: Jazyk - stikh - smysl v russkoj poezii XVIII-XX vekov. Vol. 1. Moskva: Jazyki russkoj kul'tury.

Shapir, Maksim Il'ich 2015. Universum versus: Jazyk - stikh - smysl v russkoj poezii XVIII-XX vekov. Vol. 2. Moskva: Jazyki slavjanskoj kul'tury. 
Stepanov, Aleksandr Gennad'evich 2010. Strofa pamjati i "pamjat”" strofy (k semantike stikhotvornoj formy). In: Kul'tura v fokuse znaka. Tver': SFK-ofis, 297-309.

Stephenson, Robert Clarence 1938. The English source of Pushkin's Spanish Themes. In: Studies in English 18, 85-111.

Taranovsky, Kirill Fedorovich 1963. O vzaimootnoshenijakh stikhotvornogo ritma i tematiki. In: American Contributions to the Fifth International Congress of Slavists. Vol. I: Linguistic Contributions. The Hague: Mouton, 287-332.

Trunin, Mikhail 2017. Towards the concept of semantic halo. In: Studia Metrica et Poetica 4(2), 41-66.

Umphrey, George W. 1946. Spanish Ballads in English. In: Modern Language Quarterly $7(1), 21-33$.

Vinokur, Grigorij Osipovich 1930. Vol'nye jamby Pushkina. In: Pushkin i ego sovremenniki: Materialy i issledovanija. Vol. 38/39. Leningrad: Izdatel'stvo AN SSSR, 23-36.

Wachtel, Michael 2006. Poeticheskaja perepiska Bloka i Akhmatovoj: Vzgljad na pervuju publikatsiju. In: Stikh, jazyk, poezija: Pamjati Mikhaila Leonovicha Gasparova. Moskva: RGGU, 154-163.

Yarkho, Boris Isaakovich (trans.) 1936. Pesn' o moem Side. In: Shor, Rozalija Osipovna (ed.), Khrestomatija po zapadnoevropejskoj literature. Literatura Srednikh vekov (IX-XV v.v.). Moskva: Uchpedgiz, 361-390.

Zhiljakova, Emma Mikhajlovna 2010. [Primechanija: "Sid”]. In: Zhukovsky, Vasilij Andreevich, Polnoe sobranie sochinenij i pisem v 20 tomakh. T. 5: Epicheskie stikhotvorenija. Moskva: Jazyki slavjanskikh kul'tur, 363-379.

Zhirmunsky, Viktor Maksimovich 1966. Stikh i perevod (Iz istorii romanticheskoj poemy). In: Russko-evropejskie literaturnye svjazi: Sbornik statej k 70-letiju so dnja rozhdenija akademika M. P. Alekseeva. Moskva, Leningrad: Izdatel'stvo AN SSSR, 423-433.

Zhirmunsky, Viktor Maksimovich 1970. Anna Akhmatova and Aleksandr Blok. In: Russkaja literatura 3, 57-82.

Zhirmunsky, Viktor Maksimovich 1975. Teorija stikha. Leningrad: Sovetskij pisatel'.

Zholkovsky, Alexander Konstantinovich 2009 [2006]. “Prosypat'sja na rassvete...” Anny Akhmatovoj: Poetika osvezhenija. In his: Novaja i novejshaja russkaja poezija. Moskva: RGGU, 56-71, 282-294. 